\title{
Short Communicaton Parental cigarette smoking and childhood risks of hepatoblastoma: OSCC data
}

\author{
T Sorahan $^{*, 1}$ and RJ Lancashire ${ }^{2}$ \\ 'Institute of Occupational Health, University of Birmingham, Edgbaston, Birmingham B/5 2TT, UK; ${ }^{2}$ Department of Public Health and Epidemiology, \\ University of Birmingham, Edgbaston, Birmingham B/5 2TT, UK
}

Reported cigarette smoking habits for the parents of 43 UK children who died with hepatoblastoma (1953-55 deaths, 197| -8 | deaths) have been compared with corresponding information for the parents of 5777 healthy control children by means of unconditional logistic regression. Hepatoblastoma risks were doubled if both parents smoked relative to neither parent smoking (RR 2.28, 95\% Cl 1.02-5.09). British Journal of Cancer (2004) 90, I016-1018. doi:10.1038/sj.bjc.660 I65 I www.bjcancer.com (c) 2004 Cancer Research UK

Keywords: hepatoblastoma; childhood cancer; parental smoking

Three reports from the Oxford Survey of Childhood Cancers have suggested that paternal but not maternal cigarette smoking is associated with increased risks for the generality of childhood cancers (Sorahan et al, 1995, 1997a, b). Other studies, however, have produced conflicting findings (Thornton and Lee, 1998; Sorahan et al, 2001) and, for example, the large study reported recently from the United Kingdom Childhood Cancer Study (UKCCS) found no important positive effects for paternal smoking and the risks of all childhood cancers (Pang et al, 2003). A significant association was reported in this latter study, however, between hepatoblastoma risks and smoking by both parents relative to neither parent smoking (RR 4.74 95\% CI 1.68-13.35, $P=0.003)$. OSCC data have been examined, therefore, to provide additional information on any relation between parental cigarette smoking and hepatoblastoma.

\section{MATERIALS AND METHODS}

The OSCC, a national case-control study into the aetiology of childhood cancer, began in Oxford in 1955, but has been located at the University of Birmingham since 1975 . The survey sought to interview the parents (usually the mother) of all children dying of cancer before their 16th birthday in England, Wales and Scotland for the period 1953-84. A number of standard questionnaires, covering a wide range of social and medical topics, were used during the course of this prolonged study. Data on parental cigarette smoking were not collected for all years of the study, but sought for 1953-55 deaths, 1971-76 deaths and 1977-81 deaths (and matched controls). The survey and the information available on smoking histories have been described previously (Stewart et al, 1958; Gilman et al, 1988; Sorahan et al 1995, 1997a,b).

A total of 5777 matched case-control pairs (all diagnoses) with smoking histories were available for analysis (Sorahan et al,

*Correspondence: Prof T Sorahan; E-mail: T.M.Sorahan@bham.ac.uk Received 5 November 2003; revised 15 December 2003; accepted 16 December 2003 1997b). The abstracts of hospital records collected contemporaneously have been reviewed for all 64 liver tumours among which 43 hepatoblastomas were identified. Case and control data relating to smoking histories were then compared by means of unconditional logistic regression using the EGRET program. The use of unconditional logistic regression enabled comparisons to be made between the cases of hepatoblastoma $(n=43)$ and the entire series of controls for whom smoking details were available $(n=5777)$. Relative risks (odds ratios) for categories of parental smoking were first estimated without adjustment for other variables. These analyses were then repeated with adjustment for three of the four original matching variables (sex of child, age at death or corresponding age for controls, year of death or corresponding year for controls). Computerised information on region of residence was not available for these analyses. Further analyses also adjusted for social class, sibship position, maternal age at birth of child, paternal age at birth of child and obstetric radiography. The procedures adopted to code social class have been described previously (Lancashire and Sorahan, 2003). The smoking histories are those analysed previously (Sorahan et al, 1997b) except that ex-smokers who gave up at least 2 years before the birth of the survey child have now been combined with the nonsmokers; ex-smokers who gave up either shortly before the birth or after the birth are classified as smokers.

\section{RESULTS}

Number of cases (hepatoblastoma and all diagnoses) and controls are shown by categories of parental smoking habits in Table 1, together with corresponding odds ratios. Three sets of odds ratios are shown: separate analyses of parental smoking habits (A), simultaneous analyses of parental smoking habits (B), and an alternative approach related to the habits of one or both parents (C). Positive associations are evident between hepatoblastoma risks and both maternal and paternal smoking. The largest relative risk is shown in the fuller model for both parents being smokers (RR 2.69, $P<0.05,95 \%$ CI 1.18-6.13). 
Table I Relative risks of hepatoblastoma and all childhood cancers in relation to parental cigarette smoking: 5777 OSCC matched pairs (I $953-55$ deaths, |97| -76 deaths, |977-8| deaths)

\begin{tabular}{|c|c|c|c|c|c|c|c|c|c|c|}
\hline \multirow[b]{2}{*}{ Diagnosis } & \multirow[b]{2}{*}{$\begin{array}{l}\text { Parental cigarette } \\
\text { smoking }\end{array}$} & & \multirow[b]{2}{*}{ Cases (n) } & \multirow[b]{2}{*}{ Controls (n) } & \multirow[b]{2}{*}{$\begin{array}{l}\mathbf{R R}^{\mathbf{a}} \\
\text { unad }\end{array}$} & \multirow[b]{2}{*}{$\begin{array}{l}(95 \% \mathrm{Cl}) \\
\text { djusted }\end{array}$} & $\mathbf{R R}^{\mathbf{b}}$ & $(95 \% \mathrm{Cl})$ & $\mathbf{R R}^{\mathbf{c}}$ & $(95 \% \mathrm{CI})$ \\
\hline & & & & & & & \multicolumn{2}{|c|}{$\begin{array}{l}\text { adjusted for } \\
\text { matching variables }\end{array}$} & \multicolumn{2}{|c|}{$\begin{array}{l}\text { additional } \\
\text { adjustments }\end{array}$} \\
\hline \multicolumn{11}{|c|}{ A. Separate analyses of maternal and paternal smoking habits } \\
\hline \multirow[t]{6}{*}{ All cancers } & maternal & non-smoker & 3091 & 3191 & 1.0 & & 1.0 & & 1.0 & \\
\hline & & smoker & 2616 & 2524 & 1.07 & (0.99 to 1.15$)$ & 1.07 & $(0.99$ to 1.15$)$ & 1.06 & (0.98 to 1.14$)$ \\
\hline & & not known & 70 & 62 & - & & - & & - & \\
\hline & paternal & non-smoker & 1975 & 2267 & 1.0 & & 1.0 & & 1.0 & \\
\hline & & smoker & 3601 & 3359 & $1.23 * * * *$ & $(1.14$ to 1.33$)$ & $1.25 * * * *$ & $(1.15$ to 1.35$)$ & $1.27 * * * *$ & ( 1.17 to 1.38$)$ \\
\hline & & not known & 201 & $15 \mid$ & - & & - & & - & \\
\hline \multirow[t]{6}{*}{ Hepatoblastoma } & maternal & non-smoker & 19 & 3191 & 1.0 & & 1.0 & & 1.0 & \\
\hline & & smoker & 24 & 2524 & 1.60 & (0.87 to 2.92$)$ & 1.62 & (0.88 to 2.98$)$ & 1.73 & (0.93 to 3.21 ) \\
\hline & & not known & 0 & 62 & - & & - & & - & \\
\hline & paternal & non-smoker & 12 & 2267 & 1.0 & & 1.0 & & 1.0 & \\
\hline & & smoker & 28 & 3359 & 1.58 & $(0.80$ to 3.10$)$ & 1.87 & (0.93 to 3.74$)$ & $2.10 *$ & ( 1.03 to 4.25$)$ \\
\hline & & not known & 3 & 151 & - & & - & & - & \\
\hline \multicolumn{11}{|c|}{ B. Simultaneous analyses of maternal and paternal cigarette smoking habits } \\
\hline \multirow[t]{6}{*}{ All cancers } & maternal & non-smoker & 3091 & 3191 & 1.0 & & 1.0 & & 1.0 & \\
\hline & & smoker & 2616 & 2524 & 1.02 & $(0.94$ to 1.10$)$ & 1.02 & $(0.94$ to 1.10$)$ & 1.01 & (0.93 to 1.09$)$ \\
\hline & & not known & 70 & 62 & - & & - & & - & \\
\hline & paternal & non-smoker & 1975 & 2267 & 1.0 & & 1.0 & & 1.0 & \\
\hline & & smoker & 3601 & 3359 & $1.23 * * * *$ & (1.13 to 1.33$)$ & $1.24 * * *$ & $(1.14$ to 1.35$)$ & $1.27 * * * *$ & (1.17 to 1.38$)$ \\
\hline & & not known & 201 & $|5|$ & - & & - & & - & \\
\hline \multirow[t]{6}{*}{ Hepatoblastoma } & maternal & non-smoker & 19 & 3191 & 1.0 & & 1.0 & & 1.0 & \\
\hline & & smoker & 24 & 2524 & 1.44 & (0.77 to 2.68$)$ & 1.40 & (0.75 to 2.62$)$ & 1.47 & (0.78 to 2.77 ) \\
\hline & & not known & 0 & 62 & - & & - & & - & \\
\hline & paternal & non-smoker & 12 & 2267 & 1.0 & & 1.0 & & 1.0 & \\
\hline & & smoker & 28 & 3359 & 1.44 & (0.72 to 2.89$)$ & 1.68 & (0.82 to 3.45$)$ & 1.88 & (0.91 to 3.89$)$ \\
\hline & & not known & 3 & $|5|$ & - & & - & & - & \\
\hline \multicolumn{11}{|c|}{ C. Simultaneous analyses of maternal and paternal cigarette smoking habits (alternative approach) } \\
\hline \multirow[t]{5}{*}{ All cancers } & neither parent & & 1385 & $|60|$ & 1.0 & & & & & \\
\hline & mother only & & 585 & 662 & 1.02 & $(0.89$ to 1.17$)$ & 1.02 & $(0.89$ to 1.17$)$ & 1.02 & $(0.89$ to 1.18$)$ \\
\hline & father only & & 1637 & 1545 & $1.23 * * *$ & $(1.11$ to 1.35$)$ & $1.24 * * *$ & $(1.12$ to 1.38$)$ & $1.28 * * *$ & (1.15 to 1.42$)$ \\
\hline & both parents & & 1946 & 1800 & $1.25 * * *$ & $(1.14$ to 1.38$)$ & $1.26 * * *$ & $(1.15$ to 1.39$)$ & $1.28 * * * *$ & (1.16 to 1.42$)$ \\
\hline & not known ${ }^{d}$ & & 224 & 169 & - & & - & & - & \\
\hline \multirow[t]{5}{*}{ Hepatoblastoma } & neither parent & & 9 & $|60|$ & 1.0 & & & & & \\
\hline & mother only & & 3 & 662 & 0.81 & (0.22 to 2.99$)$ & 0.80 & $(0.21$ to 2.97$)$ & 0.85 & (0.23 to 3.19$)$ \\
\hline & father only & & 8 & 1545 & 0.92 & (0.35 to 2.39$)$ & 1.10 & (0.42 to 2.91$)$ & 1.23 & (0.46 to 3.28 ) \\
\hline & both parents & & 20 & 1800 & 1.98 & (0.90 to 4.35$)$ & $2.28 *$ & ( 1.02 to 5.09$)$ & $2.69 *$ & $(1.18$ to 6.13$)$ \\
\hline & not known ${ }^{d}$ & & 3 & 169 & - & & - & & - & \\
\hline
\end{tabular}

$* P<0.05, * * P<0.01$, **** $P<0.001$. a Obtained from unconditional logistic regression using all controls as comparison group. ${ }^{\mathrm{b}}$ As footnote a, adjusting for sex of child, age at death or corresponding age for controls $(0-3,4-7,8-15 y)$, and year of death or corresponding year for controls (1953-55, 197|-76, 1977-81). 'As footnote b, additional adjustment for social class (I, II, III, IV, V), sibship position (I, 2, 3, 4, $\geqslant 5$ ), age of mother at birth of survey child $(<20,20-24,25-29,30-34,35-39$, $\geqslant 40$ y), age of father at

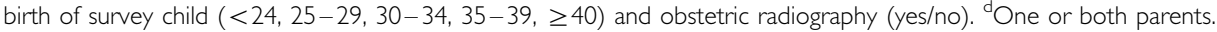

\section{DISCUSSION}

The current analysis ignores the original individual matching but the findings for all cancers are similar to those obtained previously from analyses in which the individual matching was maintained (Sorahan et al, 1997b). The analyses depended on self-reported histories, and questions directed at habits either before the relevant pregnancy (1977-81 deaths) or at the time of interview (1953-55 deaths, $1971-76$ deaths). There was no requirement for ex-smokers to identify themselves, and only a small percentage did so (Sorahan et al, 1995, 1997b). The deaths of the case children may have influenced the information supplied by case mothers. In addition, participation rates in the later phases of the OSCC were modest (Sorahan et al, 1995, 1997b). There is thus scope for biased comparisons of cases and controls. It is difficult to imagine, however, how a bias focused on hepatoblastoma could have been introduced. Hepatoblastoma is a rare cancer and the size of the current case series was only 43 (compared with 28 such cases in the UKCCS). This study provides considerable support, therefore, to the hypothesis that parental cigarette smoking is a risk factor for childhood hepatoblastoma (Pang et al, 2003; Pang and Birch, 2003). It is possible to speculate that the importance of both parents smoking in the aetiology of hepatoblastoma might arise from the combination of oxidative damage to sperm DNA (Fraga et al, 1996) and damage to the fetal liver from carcinogenic metabolites in the blood of the pregnant mother. 


\section{ACKNOWLEDGEMENTS}

We thank Jaswant Bal and Ivy Peck for earlier reabstraction of the smoking histories and Margaret Williams for word processing. We

\section{REFERENCES}

Fraga CG, Motchnik PA, Wyrobek AJ, Rempel DM, Ames BN (1996) Smoking and low antioxidant levels increase oxidative damage to sperm DNA. Mutat Res 351: 199-203

Gilman EA, Kneale GW, Knox EG, Stewart AM (1988) Pregnancy X-rays and childhood cancers: effects of exposure age and radiation dose. $J$ Soc Radiol Prot 8: 9-18

Lancashire RJ, Sorahan T (2003) Breastfeeding and childhood cancer risks: OSCC data. Br J Cancer 88: 1035 - 1037

Pang D, Birch JM (2003) Smoking and hepatoblastoma: confounding by birth weight? Br J Cancer 89: 602-603

Pang D, McNally R, Birch JM (2003) Parental smoking and childhood cancer: results from the United Kingdom Childhood Cancer Study. $\mathrm{Br} \mathrm{J}$ Cancer 88: $373-381$

Sorahan T, Lancashire R, Hulten MA, Peck I, Stewart AM (1997a) Childhood cancer and parental use of tobacco from 1953 to 1955. Br J Cancer 75: 134-138 thank Professor Jillian Birch for advice about classification of childhood cancer diagnoses; responsibility for the classifications made rests with the authors. We are grateful to the late Professor Alice Mary Stewart for the legacy of the OSCC.
Sorahan T, Lancashire R, Prior P, Peck I, Stewart A (1995) Childhood cancer and parental use of alcohol and tobacco. Ann Epidemiol 5: $354-359$

Sorahan T, McKinney PA, Mann JR, Lancashire RJ, Stiller CA, Birch JM, Dodd HE, Cartwright RA (2001) Childhood cancer and parental use of tobacco: findings from the inter-regional epidemiological study of childhood cancer (IRESCC). $\mathrm{Br} \mathrm{J}$ Cancer 84: $141-146$

Sorahan T, Prior P, Lancashire RJ, Faux SP, Hulten MA, Peck IM, Stewart AM (1997b) Childhood cancer and parental use of tobacco: deaths from 1971 to 1976. Br J Cancer 76: $1525-1531$

Stewart AM, Webb J, Hewitt D (1958) A survey of childhood malignancies. $B M J$ i: $1495-1508$

Thornton AJ, Lee PN (1998) Parental smoking and risk of childhood cancer: a review of the evidence. Indoor Built Environ 7: 65-86 